\title{
20. NEOGENE AND PLEISTOCENE RADIOLARIANS FROM DEEP SEA DRILLING PROJECT LEG 79 IN THE REGION OF THE MAZAGAN PLATEAU, OFF CENTRAL MOROCCO ${ }^{1}$
}

\author{
Monique Labracherie, Département de Géologie et Océanographie, Université de Bordeaux I²
}

\begin{abstract}
At Sites 545 and 547, samples of middle and early Miocene age yielded a sufficient number of identifiable radiolarians to allow zonal age determinations and comparison with the previously established zonation in tropical latitudes. The Miocene evolution of paleoenvironments along the Northwest African continental margin is considered.
\end{abstract}

\section{INTRODUCTION}

Relatively few Neogene and Pleistocene cores off central Morocco from DSDP Leg 79 contained siliceous remains (diatoms and radiolarians). Only two of the holes (545 and 547A) recovered layers of radiolarian-bearing sediments. Miocene sequences of well-preserved radiolarian assemblages were sampled at Site 545 at $33^{\circ} 39.9^{\prime} \mathrm{N}$, $9^{\circ} 21.9^{\prime} \mathrm{W}$, water depth $\sim 3150 \mathrm{~m}$. At Site 547 , at $33^{\circ}$ $46.8^{\prime} \mathrm{N}, 9^{\circ} 21.0^{\prime} \mathrm{W}$, water depth $\sim 3940 \mathrm{~m}$, rather poorer radiolarian assemblages have been found. The Quaternary period is marked by a scarcity of radiolarians. Radiolarian specimens have been detected only within a short interval at Site 545. Miocene sedimentation was punctuated by episodes containing older, reworked faunal elements.

\section{PROCEDURES}

The primary objective of this study was to carry out a biostratigraphic investigation of Miocene sediments off central Morocco in an area that lies in the subtropical belt.

After the first analysis of core-catcher samples was made aboard ship, five to six samples were taken from each core containing radiolarians. Sampling, when core catchers did not reveal any radiolarians, was widely spaced. A total of 140 samples was examined to determine the core intervals bearing siliceous organisms.

The core samples were prepared according to the standard technique described by Riedel and Sanfilippo (1977). After sieving at $45 \mu \mathrm{m}$, permanent strew slides of the coarse fraction (three for each sample) were studied. The total abundance of radiolarians and relative abundance of species was estimated. The radiolarian species selected for this paper were chosen because of their well-established stratigraphic usefulness (Riedel and Sanfilippo, 1971, 1978). Moreover, additional radiolarian specimens have been noted with a view toward a better understanding of the paleogeographic environmental question.

\section{RADIOLARIANS AT EACH SITE}

The information on the presence of Miocene radiolarians is summarized in Tables 1 and 2 for those cores in which significant radiolarian assemblages have been identified. The relative abundance of radiolarians and

\footnotetext{
${ }^{1}$ Hinz, K., Winterer, E. L., et al., Init. Repts. DSDP, 79: Washington (U.S. Govt. Printing Orfice)

2 Address: Département de Gtologie et Octeanographie, Université de Bordeaux 1, Ave-
} nue des Facultes, 33405 Talence, Cedex, France. the relative proportion of the total radiolarian assemblage in each sample is indicated as follows: abundant $(A)$, common $(C)$, few $(F)$, or rare (R). A dash (-) indicates that no specimens were detected (Table 2). Preservation of the specimens is indicated as good $(\mathrm{G})$, moderate $(\mathrm{M})$, or poor $(\mathrm{P})$.

These same terms are used to indicate in a semiquantitative fashion the proportion of the diatom assemblage associated with the radiolarian assemblage in the coarse fraction (see Table 1).

\section{Site 545}

Radiolarians occur in the upper Pleistocene (depth = 9-18 m). Significant quantities of radiolarians were identified in the lower-middle Miocene (depth $=217-251 \mathrm{~m}$ ).

\section{Pleistocene}

Core 545-2 contains rare to common radiolarians, poorly preserved, of Pleistocene age. The more abundant assemblage appears within sections 6 and 7 (545-2-6, $103-106 \mathrm{~cm} ; 545-2-7,20-24 \mathrm{~cm})$. It includes Amphirhopalum ypsilon, Eucyrtidium acuminatum, Lamprocyclas maritalis, Theocorythium trachelium, and other species belonging to the genera Stylodictya and Polysolenia. All species are considered warm temperate water elements and have been found in Recent sediments at middle latitudes of the Atlantic Ocean (Labracherie, 1978). Typical tropical species are virtually absent (e.g., Euchitonia elegans, Pterocanium praetextum praetextum, Spongaster tetras tetras). Stylatractus universus is missing from this relatively well-preserved assemblage. The globally synchronous extinction of $S$. universus, detected near the isotope Stage 11-12 boundary, is a good biostratigraphic indicator (Hays and Shackleton, 1976). Whereas the transition between Stages 12 and 11 has been estimated at 440,000 yr. ago (Shackleton and Opdyke, 1976) it is assumed that the radiolarian assemblage from Core 545-2 is younger than $440,000 \mathrm{yr}$.

Radiolarians are absent in samples from Core 545-3 through Core 545-23. Sample 545-23-7, 12-15 cm yielded some highly corroded, unidentifiable radiolarian fragments. 


\section{Miocene}

Cores 545-24 to 545-27 represent a Miocene section in which radiolarians are common to abundant and sometimes well preserved (see Table 1). Because of the occurrence of intermediate populations in the typical lineages, or of the scarcity of the common stratigraphic indicator species from tropical regions, there are some difficulties in the biostratigraphic interpretation and uncertainties in sharply identifying zonal boundaries. Samples contain radiolarian assemblages of both tropical and Mediterranean affinities.

The assemblage at the top of Core 545-24 (Samples 545-24-1, 46-49 $\mathrm{cm}$ to $545-24-4,70-73 \mathrm{~cm}$ ) belongs to the Dorcadospyris alata Zone defined by Riedel and Sanfilippo $(1971,1978)$. Specimens recorded as D. alata are outnumbered by a population that is intermediate between $D$. dentata Haeckel and D. alata (Riedel). Similar atypical forms have been described by Sanfilippo et al. (1973, p. 218, pl. 3, fig. 2) in the Mediterranean regions and have been interpreted as $D$. dentata according to the angle of the feet. In the material off Morocco, the feet generally diverge at an angle of much less than $180^{\circ}$; however, this camber is highly variable. It would seem that there is a very progressive transition from $D$. denta$t a$, only represented by the Sanfilippo and Riedel atypical form (Sanfilippo et al., 1973), to the species D. alata.

Generally, the genus Calocycletta is well represented and highly diversified in the Miocene of tropical regions. Three species have been identified off central Morocco and the most important is $C$. virginis. The second species includes forms resembling $C$. robusta. $C$. costata is very rare. As in the Majorcan assemblage (Sanfilippo et al., 1973), specimens are more slightly costate. The assemblage representing the Calocycletta costata Zone could occur at the bottom of Core 545-24.

At the top of Core 545-25, the abruptness of appearances and disappearances of taxa could characterize the upper limit of the Stichocorys wolffii Zone but could also be indirect evidence of some unconformity within the section. At the boundary between the Calocycletta costata Zone and the Stichocorys wolffii Zone, Cannartus prismaticus has a well-defined upper limit. This level coincides with the top of Lychnocanoma elongata and the first appearance of Cannartus mammifer. This pattern may be compared to those observed at other DSDP sites (Moore, 1971). The boundary between the Stichocorys wolffii Zone and Stichocorys delmontensis Zone could be determined between Cores 545-25 and 545-26 based on the appearance of the $S$. wolffii. Dorcadospyris ateuchus also have a well-defined upper limit at this level. In addition, the last occurrence of the $D$. ateuchus is a good stratigraphic indicator. $D$. dentata occurs just above this boundary. Theocyrtis annosa is common in the lowermost sample, yielding well-preserved radiolarians (545-27-2, 50-53 cm). In earlier interpretations, the upper limit of $T$. annosa is used to define the base of the Stichocorys delmontensis Zone (Riedel and Sanfilippo, 1978). Unfortunately, older samples within Core 545-27 contain only very poorly preserved radiolarian fragments with some Orosphaeridae.

\section{Site 547}

Radiolarians are absent from Core 547A-1 to 547A-7-1, $70-74 \mathrm{~cm}$. Some samples from Cores $547 \mathrm{~A}-8$ to $547 \mathrm{~A}-14$ yielded very rare, undeterminable radiolarian fragments. Dinocysts are very common in the slide preparations. Samples at the top of Core 547A-14 contain some very rare, pyritized radiolarian fragments and Orosphaeridae. Samples from Core 547A-14 (547A-14-4, 87-91 cm; $547 \mathrm{~A}-14, C \mathrm{C})$ and from Section $547 \mathrm{~A}-15-2$ contain varied radiolarian assemblages of early Miocene age (see Table 2). Assignment to the Stichocorys wolffii Zone, near the $S$. wolffii/S. delmontensis zonal boundary, is based on comparison with the assemblages determined at Site 545. Three samples examined from Core 547A-16

Table 1. Abundance of some Miocene radiolarians from Site 545.

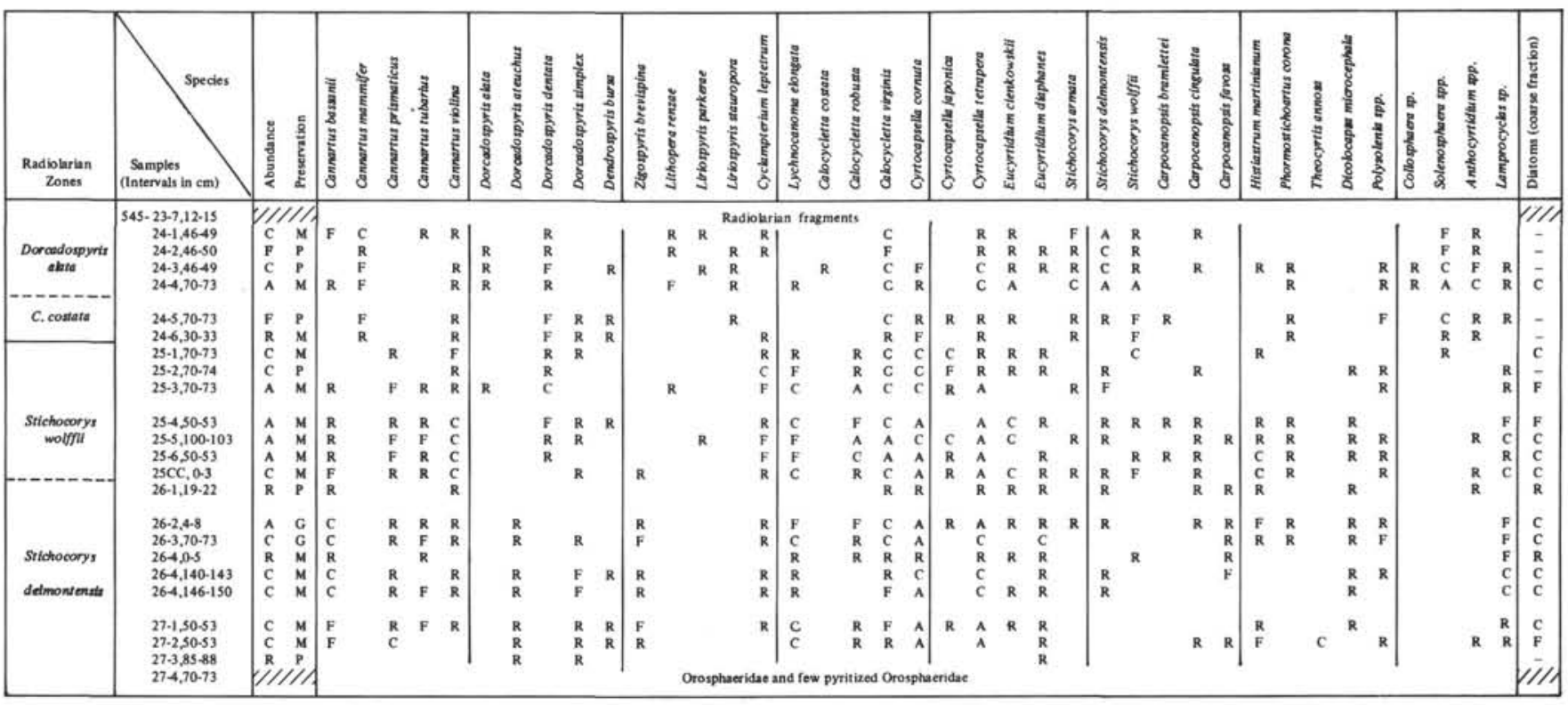


Table 2. Abundances of some Miocene radiolarians from Hole 547A.

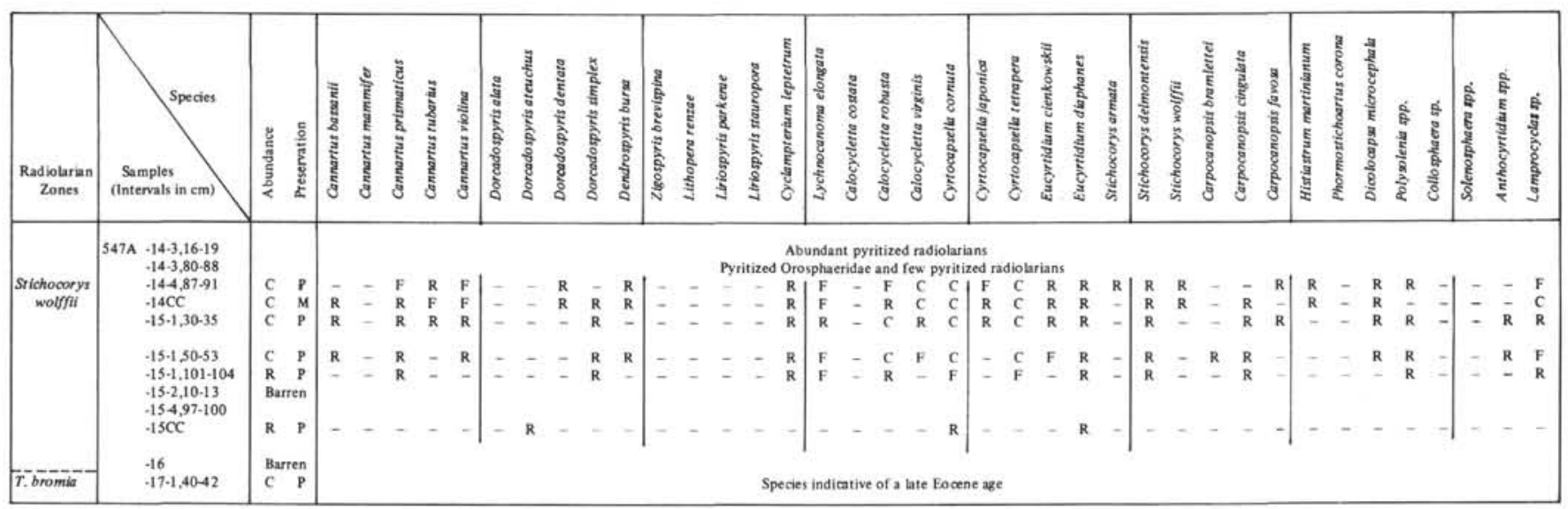

contain no radiolarians. The upper Eocene of Core 547A-17 (547A-17-1, 40-42 cm; 547A-17-2, 36-39 cm) contains scarce and poorly preserved radiolarians that are associated with diatoms. Among the radiolarian fragments, Podocyrtis chalara, Dorcadospyris triceros, Thyrsocyrstis tetracantha, and Lychnocanoma bellum have been identified.

\section{PALEOGEOGRAPHY}

Lower and middle Miocene Cannartus species are fairly well represented among the mid-latitude radiolarian assemblages off central Morocco. C. bassanii, encountered in Mediterranean regions (Sanfilippo et al., 1973), could be considered as a middle latitude species from the eastern Atlantic Ocean. It is found off the African coasts from Cape Bojador to offshore central Morocco. More southern occurrences are rare (Johnson, 1977). In the Morocco basin, $C$. bassanii is found within the early Miocene and more abundantly in the Stichocorys delmontensis Zone. Westberg et al. (1980) have not found it in upper lower Miocene sediments. It is replaced here quantitatively by Cannartus violina.

Species belonging to the genus Dorcadospyris are common but transitions in this genus are not well understood. $D$. forcipata is normally a component of radiolarian assemblages within the lower Miocene zones of tropical regions (Riedel and Sanfilippo, 1971; Moore, 1971; Johnson, 1974). It is virtually absent off the Moroccan coast. It is present in sections of the eastern tropical Atlantic (Sierra Leone Rise) but occurs very rarely northwards (off Cape Bojador) (Johnson, 1977). One of the dominant characteristics in the middle latitude Dorcadospyris assemblage off central Morocco is the absence of a strong apical horn.

Zygospyris brevispina has been observed in the Mediterranean Neogene (Sanfilippo et al. 1973) but has not yet been encountered in the eastern Atlantic Ocean. At Site 545 Zygospiras brevispina has a restricted range (Table 1). Its upper limit corresponds approximately with the first appearance of Dorcadospyris dentata.

At the Moroccan margin sites the early Miocene assemblage includes numerous specimens of several species belonging to the genus Cyrtocapsella. Stichocorys armata and Cannartus mammifer are also better represented within Miocene sequences off central Morocco than in southern tropical regions (Johnson, 1977). Again, the very close resemblance between the middle latitude radiolarians of early and middle Miocene age from the eastern Atlantic Ocean and the Mediterranean assemblages is noted (Sanfilippo et al., 1973). These affinities have already been described by Johnson (1977) for Site 369 at latitude $26^{\circ} \mathrm{N}$. They seem to be more important around latitude $33^{\circ} \mathrm{N}$.

\section{PALEOENVIRONMENT}

Taxa belonging to the collosphaerid family are rather common at Site 545. Species belonging to the genera Collosphaera and Solenosphaera have a limited stratigraphic range. They are observed throughout the Dorcadospyris alata and Calocycletta costata zones (Table 1). In Recent sediments Collosphaera and Solenosphaera are particularly abundant in tropical regions. At Site 545 , they are associated with species belonging to the genus Anthocyrtidium which is also found in low latitude Holocene sediments in the Atlantic Ocean (Goll and Bjørklund, 1971). These species, with a well-defined distribution, may be indicative of a warming during the Miocene in the coastal waters off Morocco. They also reveal markedly warmer temperatures of surface coastal waters during the end of early Miocene and at the beginning of middle Miocene in comparison to modern times.

A high biogenous opal content in marine sediments is probably a signal recording the high level of nutrients in surface waters. Furthermore, abundant diatoms in the coarse fraction may reflect a coastal upwelling influence (Diester-Haass, 1978; Berger et al., 1978; Labracherie, 1980a). Off the coasts of North and Northwest Africa, between $18^{\circ}$ and $33^{\circ} \mathrm{N}$, the biogenous opal content in Recent sediments decreases from south to north. Upwelling processes extend as far as $30^{\circ} \mathrm{N}$, but the highest intensity has been found in the vicinity of Cape Blanc $\left(21^{\circ} \mathrm{N}\right)$. Near latitude $21^{\circ} \mathrm{N}$, biosiliceous sedimentation during the latest Pleistocene can be linked to climatic variations. For example, the last glacial period (at the time of deglaciation) shows a strongly increased influ- 
ence of upwelling processes (high proportions of diatoms) and nutrient-richer intermediate depth water masses that have a southern origin (abundance of some radiolarians) (Labracherie et al., in press).

Off central Morocco numerous well-preserved radiolarians are associated with rich diatom assemblages (coarse fraction) during the early Miocene ( $S$. delmontensis Zone and lower part of the $S$. wolffii Zone) (Table 1). Such an assemblage may reflect upwelling influence in a coastal area. Miocene upwelling could then be compared with the highly productive coastal upwelling of the glacial regimes during the late Pleistocene (Labracherie, 1980b). During the late early Miocene (C. costata Zone) rare diatoms are evident in the coarse biosiliceous fraction which is itself less well preserved. This change may support the idea of a weaker upwelling at this time. During the following phase (boundary early-middle Miocene and the lower part of the $D$. alata Zone), the radiolarian association suggests warmer coastal waters. Both this increase of surface temperatures and the absence of diatoms could be correlated to a migration of the upwelling center in relation to one of the highest Tertiary sea levels (von Rad and Wissmann, 1982). Such a situation could tentatively be compared to that described off Northwest Africa during the last transition from a Quaternary glacial to an interglacial mode featuring a shifting of upwelling center from the lower to upper continental slope (Diester-Haass, 1977). Moreover, as far as the Quaternary distribution of siliceous organisms in the same region is concerned, both diatoms and radiolarians were detected in sediments underlying very fertile areas (upwelling center) whereas only radiolarians were found offshore (Labracherie, 1980b).
Finally, the biogenic silica accumulation (radiolarianbearing sediments) during the Miocene from $S$. delmontensis Zone to $C$. costata Zone is rather uniform along the Northwest African continental margin, between $20^{\circ}$ and $33^{\circ} \mathrm{N}$. A highly productive upwelling correlated with nutrient-rich waters and reflected by diversified and wellpreserved radiolarian assemblages characterizes the nearest sites of the adjacent continent (Sites 140, 369, 415, and 545) (Fig. 1). At more oceanic sites, productivity is less important (Sites 138, 141, 368, and 416).

At the end of middle Miocene the absence of radiolarians, except at Holes 139 and 369A (Fig. 1) may suggest that upwelling influence was less extensive and possibly concentrated between $23^{\circ}$ and $26^{\circ} \mathrm{N}$. Paleopositions of these sites at middle Miocene coincide with the highest fertility area for modern upwelling. Such an evolution has been correlated to a southward shift in wind regimes (Sarnthein et al., 1982).

The absence of radiolarians from sediments above the middle Miocene off Northwest Africa could indicate surface and subsurface waters were nutrient poor and suggest a calmer surface water circulation.

\section{CONCLUSIONS AND SUMMARY}

At Sites 545 and 547, samples yielded a sufficient number of identifiable radiolarians to allow zonal age determinations and comparisons with the previously established zonations in tropical latitudes.

During the early Miocene, high biogenous opal contents in sediments off Morocco signal an enhanced fertility induced by upwelling. Radiolarian assemblages suggest warming of coastal waters at the beginning of the middle Miocene and at the same time a weaker and vari-

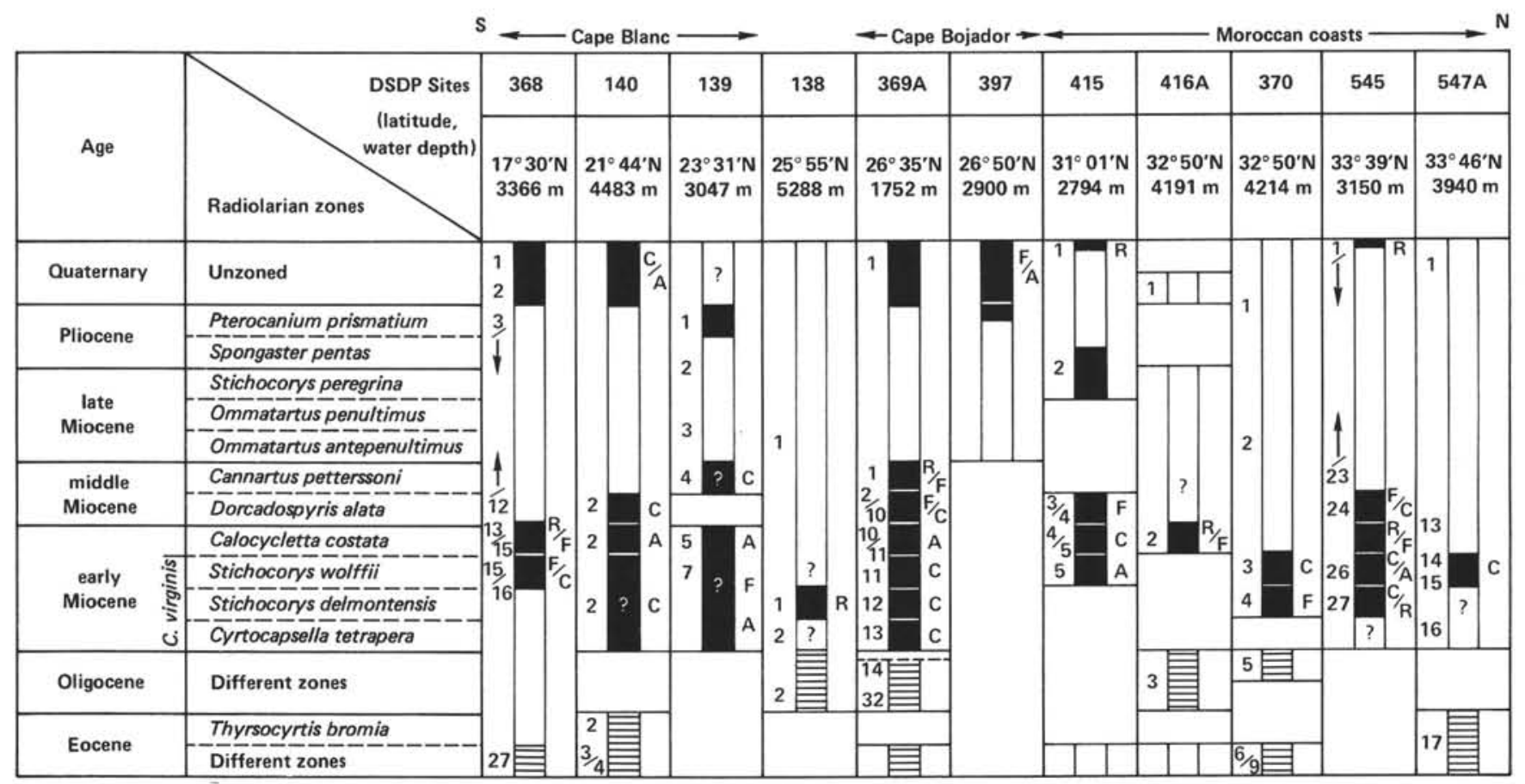

Figure 1. DSDP Sites drilled along the African margin (Legs 14, 41, 50, 79) with cores containing Miocene radiolarians (black squares) or Paleogene radiolarians (hatched squares) and approximate correlations (see Petrushevskaya and Kozlova, 1972; Johnson, 1977; Westberg et al., 1980; and this report). Core numbers on left and estimated abundance on right. At the Leg 14 sites, age assignment is uncertain because of the zonation used at that time (the $C$. virginis zone without subdivision). Abundance is described as A, abundant; $C$, common; $F$, few; $R$, rare. 
able upwelling. The disappearance of biogenic silica in sediments above the middle Miocene off the Northwest African continental margin is correlated to a calmer surface water circulation.

\section{ACKNOWLEDGMENTS}

The samples for this study were kindly provided by Peter Baumgartner, DSDP Staff Scientist for Leg 79. The analytical part of this work was performed with the financial support of the Centre National de la Recherche Scientifique, through L.A. 197 at the Université de Bordeaux I, and the Institut de Géologie du Bassin d'Aquitaine, in Bordeaux. I am very grateful to Dora Morel, Bordeaux, for carefully correcting the English language in an earlier version of this paper. This paper was also improved by the critical reviews of D. A. Johnson, Woods Hole Oceanographic Institution, Woods Hole, MA (U.S.A.) and W. R. Riedel, Scripps Institution of Oceanography, La Jolla, CA (U.S.A.).

\section{REFERENCES}

Berger, W. H., Diester-Haass, L., Killingley, J. S., 1978. Upwelling off North-West Africa: the Holocene decrease as seen in carbon isotopes and sedimentological indicators. Oceanol. Acta, 1: 3-7.

Campbell, A. S., and Clark, B. L., 1944. Miocene radiolarian faunas from Southern California. Geol. Soc. Am., Spec. Pap., 51:1-76.

Diester-Haass, L., 1977. Radiolarian/planktonic foraminiferal ratios in a coastal upwelling region. J. Foraminiferal Res., 7(no. 1):26-33. 1978. Sediments as indicators of upwelling. In Boje, R., and Tomczak, M. (Eds.), Upwelling Ecosystems: (SpringerVerlag), 261-280.

Goll, R. M., 1968. Classification and phylogeny of Cenozoic Trissocyclidae (Radiolaria) in the Pacific and Caribbean basins, part I. J. Paleontol., 42:1409-1432.

Goll, R. M., and Bjørklund, K. R., 1971. Radiolaria in surface sediments of the North Atlantic Ocean. Micropaleontology, 17(no. 4): 434-454.

Haeckel, E., 1887. Report on the Scientific Results of the Voyage of H.M.S. Challenger during the Years 1873-76. Zoology, Vol. 18: Report on the Radiolaria.

Hays, J. D., and Shackleton, N. J., 1976. Globally synchronous extinction of the radiolarian Stylatractus universus. Geology, 4:649-652.

Johnson, D. A., 1974. Radiolaria from the eastern Indian Ocean, DSDP Leg 22. In von der Borch, C. C., Sclater, J. G., et al., Init. Repts. DSDP, 22: Washington (U.S. Govt. Printing Office), 521-575.

1977. Cenozoic radiolaria from the eastern tropical Atlantic, DSDP Leg 41. In Lancelot, Y., Seibold, E., et al., Init. Repts. DSDP, 41: Washington (U.S. Govt. Printing Office), 763-783.

Labracherie, M., 1978. Distribution des thanatocénoses récentes de radiolaires dans l'Atlantique nord-oriental et le Sud de la mer de Norvège. Boreas, 7:205-213.

1980a. Les radiolaires témoins de l'évolution hydrologique depuis le dernier maximum glaciaire au large du Cap Blanc (Afrique du Nord-Ouest): Palaeogeogr., Palaeoclimatol., Palaeoecol., $32: 163-184$

, 1980b. Modifications de la circulation océanique au large du Cap Blanc (Afrique du Nord-Ouest) entre le dernier maximum glaciaire et l'époque actuelle. Apport des diatomées et des radiolaires. C. R. Acad. Sci., Paris, 291(no. 7):601-604.

Labracherie, M., Barde, M. F., Moyes, J., and Pujos-Lamy, A., in press. Variability of upwelling regimes (Northwest Africa and South Arabia) during the latest Pleistocene. A comparison. In Suess, E., and Thiede, J., Coastal upwelling: its Sediment Record: (Plenum Publishing Corporation).

Moore, T. C., 1971. Radiolaria. In Tracey, J. L., Jr., Sutton, G. H., et al., Init. Repts. DSDP, 8: Washington (U.S. Govt. Printing Office), 727-775.

1972. Mid-Tertiary evolution of the radiolarian genus Calocycletta. Micropaleontology, 18:144-152.

Nigrini, C., 1967. Radiolaria in pelagic sediments from the Indian and Atlantic Ocean. Bull. Scripps Inst. Oceanogr., Univ. Calif., San Diego, La Jolla, CA, 11:1-125.
Petrushevskaya, M. G., and Kozlova, G. E., 1972. Radiolaria: Leg 14, Deep Sea Drilling Project. In Hayes, D. E., Pimm, A. C., et al., Init. Repts. DSDP, 14: Washington (U.S. Govt. Printing Office), 495-648.

Riedel, W. R., 1959. Oligocene and Lower Miocene Radiolaria in tropical Pacific sediments. Micropaleontology, 5:285-302.

Riedel, W. R., and Sanfilippo, A., 1970. Radiolaria, Leg 4. Deep Sea Drilling Project. In Bader, R. G., Gerard, R. D., et al., Init. Repts. $D S D P, 4$ : Washington (U.S. Govt. Printing Office), 503-575.

1971. Cenozoic Radiolaria from the western tropical Pacific, Leg 7. In Winterer, E. L., Riedel, W. R., et al., Init. Repts, DSDP, 7, Pt. 2: Washington (U.S. Govt. Printing Office), 15291672.

1977. Cenozoic Radiolaria. In Ramsay, A. T. S. (Ed.), Oceanic Micropaleontology: (Academic Press), 847-912.

1978. Stratigraphy and evolution of tropical cenozoic radiolarians. Micropaleontology, 24(no. 1):61-96.

Sanfilippo, A., Burckle, L. H., Martini, E., and Riedel, W. R., 1973. Radiolarians, diatoms, silicoflagellates and calcareous nannofossils in the Mediterranean Neogene. Micropaleontology, 19(no. 2): 209-234.

Sanfilippo, A., and Riedel, W. R., 1970. Post-Eocene "closed" theoperid radiolarians. Micropaleontology, 16(4):446.

1973. Cenozoic Radiolaria (exclusive of theoperids, artostrobiids and amphipyndacids) from the Gulf of Mexico. DSDPLeg 10. In Worzel, J. L., Bryant, W., et al., Init. Repts. DSDP, 10: Washington (U.S. Govt. Printing Office), 475-611.

Sarnthein, M., Thiede, J., Pflaumann, U., Erlenkeuser, H., Fütterer, D., Koopmann, B., Lange, H., and Siebold, E., 1982. Atmospheric and oceanic circulation Patterns off Northwest Africa during the Past 25 Million years. In von Rad, U., Hinz, K., et al., Geology of the Northwest African Continental Margin: (Springer-Verlag), 545-604.

Shackleton, N. J., and Opdyke, N., 1973. Oxygen isotope and paleomagnetic stratigrapy of equatorial Pacific core V 28-239: Oxygen isotope temperatures and ice volumes on a $10^{5}$ to $10^{6}$ year scale. Quat. Res., 3:39-55.

von Rad, U., and Wissman, G., 1982. Cretaceous-Cenozoic History of the west Saharan Continental Margin (NW Africa): Development, Destruction and Gravitational sedimentation. In von Rad, U., Hinz, K., et al., Geology of the Northwest African continental margin: (Springer-Verlag) 117-129.

Westberg, M. J., Sanfilippo, A., and Riedel, W. R., 1980. Radiolarians from the Moroccan Basin, Deep Sea Drilling Project, Leg 50. In Lancelot, Y., Winterer, E. L., et al., Init. Repts. DSDP, 50: Washington (U.S. Govt. Printing Office), 429-437.

Date of Initial Receipt: November 2, 1982

Date of Acceptance: May 20, 1983

\section{APPENDIX \\ Species List}

Amphirhopalum ypsilon Haeckel. Amphirhopalum ypsilon Haeckel, 1887. p. 522; Nigrini, 1967 , p. 35 , pl. 3 , figs. 3a-d.

Anthocyrtidium spp. Sanfilippo and Riedel. Anthocyrtidium spp. Sanfilippo and Riedel in Sanfilippo et al., 1973, p. 224, pl. 6, fig. 9.

Calocycletta costata (Riedel). Calocyclas costata Riedel, 1959, p. 296, pl. 2, fig. 9. Calocycletta costata (Riedel) Riedel and Sanfilippo, 1970 , p. 535, pl. 14, fig. 12; Moore, 1972, p. 147, pl. 1, fig. 8; Sanfilippo and Riedel in Sanfilippo et al., 1973, p. 226, pl. 6, fig. 10.

Calocycletta robusta Moore group. Calocycletta robusta Moore, 1971, p. 743 , pl. 10, fig. 5, 6. Calocycletta caepa Moore, 1972, p. 150, pl. 2, fig. 4, 7. Calocycletta robusta Moore group, Riedel and Sanfilippo, 1978, p. 66, fig. 3, figs. 10-11.

Calocycletta serrata Moore. Calocycletta serrata Moore, 1972, p. 148, pl. 2, fig. 1-3.

Calocycletta virginis (Haeckel). Calocyclas (Calocycletta) virginis Haeckel, 1887, p. 1381, pl. 74, fig. 4. Calocycletta virginis Haeckel, Riedel, 1959, p. 295, pl. 2, fig. 8; Riedel and Sanfilippo, 1970, p. 535, pl. 14, fig. 10; Moore, 1972, p. 147, pl. 1, fig. 7.

Cannartus bassanii (Carnevale). Cannartus bassanii (Carnevale) Sanfilippo and Riedel in Sanfilippo et al., 1973. p. 216, pl. 1, figs. 1-3. 
Cannartus mammifer (Haeckel). Cannartidium mammiferum Haeckel, 1887 , p. 375 , pl. 39, fig. 16; Cannartus mammiferus (Haeckel), Riedel, 1959, p. 291, pl. 1, fig. 4.

Cannartus prismaticus (Haeckel). Pipettella prismatica Haeckel, 1887, p. 305, pl. 39, fig. 6. Cannartus prismaticus (Haeckel), Riedel and Sanfilippo, 1970 , p. 520 , pl. 15, fig. 1; Riedel and Sanfilippo, 1971, p. 1588, pl. 2C, figs. 11-13.

Cannartus tubarius (Haeckel). Pipettaria tubaria Haeckel, 1887, p. 339, pl. 39, fig. 15. Cannartus tubarius (Haeckel), Riedel, 1959, p. 289, pl. 1, fig. 2; Riedel and Sanfilippo, 1970, p. 520, pl. 15, fig. 2; Riedel and Sanfilippo, 1978, p. 67, pl. 4, fig. 3.

Cannartus violina Haeckel. Cannartus violina Haeckel, 1887, p. 358, pl. 39 , fig. 10; Riedel, 1959 , p. 290 , pl. 1, fig. 3 ; Moore, 1971 , pl. 12, fig. 4; Riedel and Sanfilippo, 1978, p. 67, pl. 4, fig. 4.

Carpocanopsis bramlettei Riedel and Sanfilippo. Carpocanopsis bramlettei Riedel and Sanfilippo, 1971, p. 1597, pl. 2G, figs. 8-14; pl. 8, fig. 7; Riedel and Sanfilippo, 1978, p. 67, pl. 4, fig. 6 .

Carpocanopsis cingulata Riedel and Sanfilippo. Carpocanopsis cingulatum Riedel and Sanfilippo, 1971, p. 1597, pl. 2G, figs. 17-21; pl. 8, fig. 8; Riedel and Sanfilippo, 1978, p. 67, pl. 4, fig. 7.

Carpocanopsis favosa (Haeckel). Cycladophora favosa Haeckel, 1887, p. 1380 , pl. 62, figs. 5, 6. Carpocanopsis favosum (Haeckel), Riedel and Sanfilippo, 1971, p. 1597, pl. 2G, figs. 15, 16; pl. 8, figs. 9-11.

Collosphaera(?) Riedel and Sanfilippo. Collosphaera(?) Riedel and Sanfilippo, 1971, p. 1586, pl. 2A, fig. 3.

Cyclampterium leptetrum Sanfilippo and Riedel. Cyclampterium leptetrum Sanfilippo and Riedel, 1970, p. 456, pl. 2, figs. 11-12; Sanfilippo and Riedel, 1971, pl. 20, figs. 9-12; Riedel and Sanfilippo, 1978 , p. 67 , pl. 4, figs. $12-13$.

Cyrtocapsella cornuta (Haeckel). Cyrtocapsa (Cyrtocapsella) cornuta Haeckel 1887, p. 1512, pl. 78, fig. 5. Cyrtocapsella cornuta (Haeckel) Sanfilippo and Riedel, 1970, p. 453, pl. 1, figs. 19-20; Sanfilippo and Riedel in Sanfilippo et al., 1973, p. 220, pl. 5, figs. 1-2; Riedel and Sanfilippo, 1978, p. 68, pl. 4, fig. 17.

Cyrtocapsella japonica (Nakaseko). Cyrtocapsella japonica (Nakaseko), Sanfilippo and Riedel, 1970, p. 452, pl. 1, figs. 13-15; Sanfilippo and Riedel in Sanfilippo et al., 1973, pl. 5, figs. 4-6.

Cyrtocapsella tetrapera (Haeckel). Cyrtocapsa (Cyrtocapsella) tetrapera Haeckel, 1887 , p. 1512, pl. 78, fig. 5. Cyrtocapsella tetrapera (Haeckel) Sanfilippo and Riedel, 1970, p. 453, pl. 1, fig. 16-18; Sanfilippo and Riedel in Sanfilippo et al., 1973, pl. 5, figs. 4-6; Riedel and Sanfilippo, 1978, p. 68, pl. 4, fig. 18.

Dendrospyris bursa Sanfilippo and Riedel. Dendrospyris bursa Sanfilippo and Riedel in Sanfilippo et al., 1973, p. 217, pl. 2, figs. 9-13.

Dicolocapsa microcephala Haeckel. Dicolocapsa microcephala Haeckel, 1887, p. 1312; Sanfilippo and Riedel, 1970, pl. 1, fig. 7.

Dorcadospyris alata (Riedel). Brachiospyris alata Riedel, 1959, p. 293, pl. 1, figs. 11-12. Dorcadospyris alata (Riedel), Riedel and Sanfilippo, 1970, p. 523, p. 15, fig. 5; Riedel and Sanfilippo, 1971, p. 1590, pl. 2D, fig. 1; Moore, 1971, pl. 11, figs. 3-4; Riedel and Sanfilippo, 1978, p. 68, pl. 5, fig. 2.

Dorcadospyris ateuchus (Ehrenberg). Dorcadospyris ateuchus (Ehrenberg), Riedel and Sanfilippo, 1970, p. 523, pl. 15, fig. 4; Riedel and Sanfilippo, 1971, pl. 2D, fig. 6, pl. 3A, figs. 9-10; Riedel and Sanfilippo, 1978, p. 68 , pl. 5, fig. 3 .

Dorcadospyris dentata Haeckel. Dorcadospyris dentata Haeckel, 1887, p. 1040, pl. 85, fig. 6; Sanfilippo and Riedel in Sanfilippo et al., 1973 , p. 218 , pl. 3, figs. $2-3$.

Dorcadospyris forcipata (Haeckel). Dipospyris forcipata Haeckel, 1887 , p. 1037, pl. 85, fig. 1. Dorcadospyris forcipata (Haeckel), Riedel and Sanfilippo, 1971, p. 1590, pl. 2D, figs. 2-3; Moore, 1971 , p. 740 , pl. 10 , figs. $1-2$.

Dorcadospyris simplex (Riedel). Dorcadospyris simplex (Riedel), Riedel and Sanfilippo, 1970, pl. 15, fig. 6.

Dorcadospyris triceros (Ehrenberg). Dorcadospyris triceros (Ehrenberg), Moore, 1971, p. 739, pl. 6, figs. 1-3.

Eucyrtidium acuminatum (Ehrenberg). Eucyrtidium acuminatum (Ehrenberg), Nigrini, 1967, p. 81, pl. 8, figs. 3a-b.

Eucyrtidium cienkowskii Haeckel. Eucyrtidium cienkowskii Haeckel, 1887, p. 1493; Sanfilippo and Riedel in Sanfilippo et al., 1973, p. 221 , pl. 5, figs. $7-11$.

Eucyrtidium diaphanes Sanfilippo and Riedel. Eucyrtidium diaphanes Sanfilippo and Riedel in Sanfilippo et al., 1973, p. 221, pl. 5, figs. 12-14; Riedel and Sanfilippo, 1978, p. 68, pl. 5, fig. 5.
Histiastrum martinianum Carnevale group. Histiastrum martinianum Carnevale group, Sanfilippo and Riedel in Sanfilippo et al., 1973, p. 217 , pl. 2, figs. 7-8.

Lamprocyclas maritalis Haeckel maritalis Nigrini. Lamprocyclas maritalis Haeckel maritalis Nigrini, 1967, p. 74, pl. 7, fig. 5.

Lamprocyclas sp. Different species belonging to the genus Lamprocyclas.

Liriospyris parkerae Riedel and Sanfilippo. Liriospyris parkerae Riedel and Sanfilippo, 1971, p. 1590, pl. 2C, fig. 15; pl. 5, fig. 4; Riedel and Sanfilippo, 1978, p. 69, pl. 5, fig. 15.

Liriospyris stauropora (Haeckel). Trissocyclus stauropora Haeckel, 1887, p. 987 , pl. 83, fig. 5. Liriospyris stauropora (Haeckel), Goll, 1968 , p. 1431 , p. 175 , figs. $1-3,7$; Riedel and Sanfilippo, 1978, p. 69 , pl. 5, fig. 16.

Lithopera renzae Sanfilippo and Riedel. Lithopera renzae Sanfilippo and Riedel, 1970, p. 454, pl. 1, figs. 21-23, 27; Riedel and Sanfilippo, 1978, p. 70, pl. 6, fig. 11.

Lophocyrtis jacchia (Ehrenberg). Lophocyrtis jacchia (Ehrenberg), Riedel and Sanfilippo, 1971, p. 1594, pl. 3C, figs. 4-5; pl. 7, fig. 16; Riedel and Sanfilippo, 1978, p. 70, pl. 7, fig. 1.

Lychnocanoma bellum (Clark and Campbell). Lychnocanoma bellum (Clark and Campbell), Riedel and Sanfilippo, 1971, p. 1595; Riedel and Sanfilippo, 1977, pl. 10, fig. 10.

Lychnocanoma elongata (Vinassa). Lychnocanoma elongata (Vinassa), Sanfilippo and Riedel in Sanfilippo et al., 1973, p. 221, pl. 5, figs. 19-20; Riedel and Sanfilippo, 1978, p. 70, pl. 7, fig. 4.

Phormostichoartus corona (Haeckel). Cyrtophormis (Acanthocyrtis) corona Haeckel, 1887, p. 1462, pl. 77, fig. 15. Phormostichoartus corona (Haeckel), Riedel and Sanfilippo, 1971, p. 1600, pl. 11, figs. 13-15; pl. 2J, figs. 1-5; Riedel and Sanfilippo, 1978, p. 71, pl. 7, fig. 12 .

Podocyrtis chalara Riedel and Sanfilippo. Podocyrtis chalara Riedel and Sanfilippo, 1970, p. 535, pl. 12, figs. 2-3; Riedel and Sanfilippo, 1978, p. 71, pl. 12, figs. 2-3.

Podocyrtis diamesa Riedel and Sanfilippo, emend. Sanfilippo and Riedel. Podocyrtis diamesa Riedel and Sanfilippo, 1970, p. 53, pl. 12, fig. 4; Sanfilippo and Riedel, 1973, p. 531, pl. 20, figs. 9-10; pl. 35, figs. 10-11; Riedel and Sanfilippo, 1978, p. 72, pl. 8, fig. 4.

Polysolenia spp. Riedel and Sanfilippo. Polysolenia spp. Riedel and Sanfilippo, 1971, p. 1586, pl. 1B, figs. 13-14; pl. 2A, figs. 11-14.

Solenosphaera spp. Riedel and Sanfilippo. Solenosphaera spp. Riedel and Sanfilippo, 1971, p. 1586, pl. 1A, figs. 19-22; pl. 2A, figs. 4-10.

Stichocorys armata (Haeckel). Cyrtophormis armata Haeckel, 1887, p. 1460 , p. 78 , fig. 17. Stichocorys armata (Haeckel), Riedel and Sanfilippo, 1971, p. 1595, pl. 2E, figs. 13-15; Sanfilippo and Riedel in Sanfilippo et al., 1973, p. 222, pl. 6, figs. 1-2.

Stichocorys delmontensis (Campbell and Clark). Stichocorys delmontensis (Campbell and Clark), Sanfilippo and Riedel, 1970, p. 451, pl. 1, fig. 9; Riedel and Sanfilippo, 1971, p. 1595, pl. 1F, figs. 5-7; pl. 2E, figs. 10-11; Riedel and Sanfilippo, 1978, p. 74, pl. 9, fig. 10.

Stichocorys diploconus (Haeckel). Stichocorys diploconus (Haeckel), Sanfilippo and Riedel, 1970, p. 451, pl. 1, figs. 31-32.

Stichocorys wolffii Haeckel. Stichocorys wolffii Haeckel, 1887, p. 1479, pl. 80, fig. 10; Riedel and Sanfilippo, 1971, pl. 2E, figs. 8-9; Riedel and Sanfilippo, 1978, p. 74, pl. 9, fig. 12.

Theocorythium trachelium (Ehrenberg) dianae (Haeckel). Theocorythium trachelium (Ehrenberg) dianae (Haeckel), Nigrini, 1967, pl. 8, figs. 1a-b; pl. 9, figs. 1a-b.

Theocyrtis annosa (Riedel). Phormocyrtis annosa Riedel, 1959, p. 295 , pl. 2, fig. 7. Theocyrtis annosa (Riedel), Riedel and Sanfilippo, 1970 , p. 535 , pl. 15, fig. 9; Riedel and Sanfilippo, 1978, p. 78, pl. 10 , fig. 3 .

Thyrsocyrtis bromia Ehrenberg. Thyrsocyrtis bromia Ehrenberg, Riedel, and Sanfilippo, 1971, p. 1596, pl. 8, fig. 6; Moore, 1971, pl. 5, figs. 1-3; Riedel and Sanfilippo, 1978, p. 78, pl. 10,figs. 4-5.

Thyrsocyrtis tetracantha (Ehrenberg). Thyrsocyrtis tetracantha (Ehrenberg), Riedel and Sanfilippo, 1970, p. 527; Moore, 1971, pl. 4, fig. 3; Riedel and Sanfilippo, 1978, p. 80, pl. 10, figs. 8-9.

Zygospyris brevispina Carnevale group. Zygospyris brevispina Carnevale group, Sanfilippo and Riedel in Sanfilippo et al., 1973, p. 219, pl. 3, figs. 17-19. 